\title{
Horizontal Shareholding As An Antitrust Violation
}

\section{Citation}

Einer Elhauge, Horizontal Shareholding As An Antitrust Violation (Harvard John M. Olin Discussion Paper Series Paper No. 834, July 2015).

\section{Published Version}

http://www.law.harvard.edu/programs/olin_center/papers/pdf/Elhauge_834.pdf

\section{Permanent link}

http://nrs.harvard.edu/urn-3:HUL.InstRepos:17741709

\section{Terms of Use}

This article was downloaded from Harvard University's DASH repository, and is made available under the terms and conditions applicable to Other Posted Material, as set forth at http:// nrs.harvard.edu/urn-3:HUL.InstRepos:dash.current.terms-of-use\#LAA

\section{Share Your Story}

The Harvard community has made this article openly available.

Please share how this access benefits you. Submit a story.

Accessibility 


\title{
HARVARD
}

JOHN M. OLIN CENTER FOR LAW, ECONOMICS, AND BUSINESS

\section{HORIZONTAL SHAREHOLDING AS AN ANTITRUST VIOLATION}

\author{
Einer Elhauge
}

Discussion Paper No. 834

$07 / 2015$

Harvard Law School

Cambridge, MA 02138

This paper can be downloaded without charge from:

The Harvard John M. Olin Discussion Paper Series: http://www.law.harvard.edu/programs/olin_center/

The Social Science Research Network Electronic Paper Collection: http://ssrn.com/abstract=2632024 


\title{
HORIZONTAL SHAREHOLDING AS AN ANTITRUST VIOLATION
}

\author{
Einer Elhauge \\ Petrie Professor of Law, Harvard Law School ${ }^{1}$
}

July 26, 2015

(C) 2015 Einer Elhauge. All rights reserved.

\begin{abstract}
Horizontal shareholdings exist when a common set of investors own significant shares in corporations that are horizontal competitors in a product market. Economic models show that such horizontal shareholdings are likely to anticompetitively raise prices when the owned businesses compete in a concentrated market. Recent empirical work not only confirms the prediction of these models, but also reveals that such horizontal shareholdings are omnipresent in our economy. I show that such horizontal shareholdings can help explain fundamental economic puzzles, including why corporate executives are rewarded for industry performance rather than just individual corporate performance, why corporations have not used recent high profits to expand output and employment, and why economic inequality has risen in recent decades. I also show that stock acquisitions that create such anticompetitive horizontal shareholdings are illegal under current antitrust law, and I recommend antitrust enforcement actions to undo them and their adverse economic effects.
\end{abstract}

An economic blockbuster has recently been exposed. A small group of institutions has acquired large shareholdings in horizontal competitors throughout our economy, causing them to compete less vigorously with each other. For example, from 201315, seven shareholders who controlled $60 \%$ of United Airlines also controlled big chunks of United's major rivals, including 27.5\% of Delta Airlines, 22.3\% of Southwest Airlines, and $20.7 \%$ of JetBlue Airlines. ${ }^{2}$ More generally, $77 \%$ of all

${ }^{1}$ I am grateful for summer research funding by Harvard Law School and for comments from Cindy Alexander, José Azar, Jonathan Baker, John Coates, Allen Ferrell, Jesse Fried, Luke Froeb, Martin Schmalz, David Schleicher, Isabel Tecu, and David Zhang.

2 See José Azar, Martin C. Schmalz \& Isabel Tecu, Anti-Competitive Effects of Common Ownership, at Online Appendix Table A, Ross School of Business Working Paper Working Paper No. 1235 (April 21, 2015), paper available at http://ssrn.com/abstract=2427345, online appendix available https://docs.google.com/viewer?a=v\&pid=sites\&srcid=ZGVmYXVsdGRvbWFpbnxtYXJ0aW5j c2NobWFsenxneDo1ZWY5YzlhNGEwMTI4YjA2 
airline stock is owned by institutional investors. ${ }^{3}$ A new econometric study shows that this sort of horizontal shareholding has made average airline prices $3-10 \%$ higher than they otherwise would have been. ${ }^{4}$

Airlines are not the only industry plagued by such horizontal shareholdings. In the banking industry, the top four shareholders of JP Morgan-Chase (BlackRock, Vanguard, Fidelity, and State Street) are also the top four shareholders of Bank of America and four of the top six shareholders of Citigroup, collectively holding 19.2\% of JP Morgan-Chase, $16.9 \%$ of Bank of America, and $21.9 \%$ of Citigroup. ${ }^{5}$ These same shareholders are also the top four shareholders of Apple (BlackRock, Vanguard, Fidelity and State Street) and four of the top five shareholders of Apple's main rival, Microsoft, with the fifth being Bill Gates whose $4.52 \%$ stake in Microsoft is behind BlackRock's 5.33\% and barely ahead of Vanguard's $4.49 \%$ and State Street's 4.39\%. ${ }^{6}$ These four horizontal shareholders collectively owned $18.4 \%$ of Apple and $17.3 \%$ of Microsoft. ${ }^{7}$ In the pharmacy market, the top five shareholders of CVS (the above four plus Wellington) are also the top five shareholders of its main rival Walgreens. ${ }^{8}$ These horizontal shareholders owned $24.6 \%$ of CVS and $19.6 \%$ of Walgreens. ${ }^{9}$

There is every reason to think the problem of horizontal shareholding is pervasive across our economy because institutional investors like BlackRock, Vanguard, Fidelity, and State Street now own around $80 \%$ of all stock in S\&P 500 corporations. ${ }^{10}$ These institutional investors also offer index funds that cover all industries and sector funds in each specific industry, so most industries likely have significant horizontal shareholdings. ${ }^{11}$ Even though individual money managers at each institutional investor may manage a smaller portfolio, institutional investors usually exercise the shareholder voting rights of all their funds jointly at the fund

\footnotetext{
${ }^{3}$ Id. at 14 .

${ }^{4}$ Id. at 3-4.

${ }^{5}$ Id. at Table $1 \mathrm{C}$.

${ }^{6} \mathrm{Id}$. at Table $1 \mathrm{~A}$.

${ }^{7}$ Id.

${ }^{8} \mathrm{Id}$. at Table $1 \mathrm{~B}$.

${ }^{9}$ Id.
}

10 See http://www.irmagazine.com/articles/shareholder-targeting-id/18761/retailshareholders-looking-out-little-guy/

11 The major exception is industries with foreign firms who are more likely to have significantly different investors. 
family level in order to maximize each institutional investor's influence on corporate governance. $^{12}$

Economic theory has long shown that horizontal shareholdings like these reduce the incentives of horizontal competitors to compete with each other. ${ }^{13}$ The reason is that firms maximize profits by competing only when the profits from taking market share away from other firms exceed the interest in keeping marketwide prices high. In competitive markets where ownership is separate, economic models prove that firms have incentives to undercut each others' prices because the profits they gain from the additional sales exceed the price reduction caused by their own conduct. Because each firm sets prices based on the same calculus, they keep undercutting each other until they drive down prices to their marginal cost, which is the most efficient level.

But the standard economic model of market competition assumes that when a firm takes away sales by undercutting their rivals' prices, the firm's owners gain the profits from those sales but lose no profit on the sales taken away from their rivals. When the owners of a firm also own that firm's rivals, the calculus is entirely different. This is easiest to see when the owners of a firm are identical to the owners of that firm's rival. In that case, when a firm undercuts its rival's price to take away a sale, the movement of the sale to the firm from the rival simply moves money from one of their owners' pockets to another; the net effect for those owners of the price cut is now simply that the prices charged by both firms are lower, thus lowering those owners' profits across both firms.

Thus, if the same shareholders own $100 \%$ of two firms, those shareholders have no incentive to have the two firms compete against each other. The shareholders need not communicate anything to management. Any management trying to honor its fiduciary duty to maximize shareholder profits will, without any communication, understand that maximizing its shareholders' profits now requires maximizing profits across both of the firms. Even if fiduciary duties do not suffice to compel such behavior, managers want to get re-elected and will realize that their shareholders will likely vote against managers that reduce those shareholders' profits across both firms. When two firms have the same shareholders, their actions on behalf of those shareholders will be precisely the same as if the two firms had merged or entered into a perfectly-enforced cartel. Actual joint decisionmaking by the management of the two firms is unnecessary for this result because the objective

\footnotetext{
${ }^{12} \mathrm{Id}$. at 34 .

${ }^{13}$ See infra Part I.
} 
function of each management is the same: maximizing the shareholder interest in the joint profits of both firms.

This anticompetitive incentive is similar, though somewhat attenuated, when the shareholders of two firms are only partially overlapping. Suppose, one firm's shareholders also own 50\% of that firm's rival. Now, the firm's shareholders will gain some profits by moving a sale from the rival to the firm, but not as much profits as if their shareholders were entirely different. Instead, a firm acting on behalf of its shareholders will realize that each sale gained by the firm costs the firm's owners not only the usual marginal cost of making the product, but also $50 \%$ of the profits those shareholders lose from having the sale taken away from the rival. The effect on firm pricing incentives is the same as if its marginal costs were increased by an amount equal to half the profits the rival loses by losing a sale. Needless to say, this reduces the incentives of each firm to price lower even if their management never communicates with each other.

Institutional investors usually actively seek to influence the corporations in which they own shares. ${ }^{14}$ The former legal counsel of a very large asset management has said that "high on the list of topics" discussed in these communications is to urge those corporations to "throw the switch from developing market share to instead exercise market power to get margins up" in particular markets. ${ }^{15}$

However, such active influence is unnecessary for horizontal shareholdings to have anticompetitive effects. Without any active communication, corporate managers know the identity of their shareholders and the fact that their shareholders also own shares in their rivals. ${ }^{16}$ To the extent those shareholders are index funds, their holdings in rivals are obvious, and in any event SEC rules require all institutional investors to disclose all their holdings quarterly. ${ }^{17}$ Managers have incentives to act on behalf of their shareholders' interests, much as political representatives act on behalf of their electorate even though the bulk of that electorate never calls them to ask for specific action. If 50\% of the votes for US President were cast in China, we

14 See infra Part III.

${ }^{15}$ Azar, Schmalz \& Tecu, supra note , at 35.

16 Id. at 11 ("The ownership structure is public information, and moreover frequently communicated in engagement meetings [with institutional investors]. Our interviews with pricing managers moreover indicate that they are well aware of their competitors' owners.”)

17 Securities Exchange Act $\S 13(f)(1)$, (f)(5)(A) (2000); 15 U.S.C. $\S 78 m(f)(1),(f)(5)(A)$ (2000); Exchange Act Rule 13f-1, 17 C.F.R. § 240.13f-1 (2005); SEC, Shareholder Reports and Quarterly Portfolio Disclosure of Registered Management Investment Companies, Securities Act Release No. 33-8393, 69 Fed. Reg. 11,244, 11,254-57 (Mar. 9, 2004). 
would expect to see US Presidents be much more solicitous to the interests of China, even if the Chinese voters never communicated those desires directly to the President. Moreover, with pervasive horizontal shareholdings, methods for executive compensation and dismissals are largely influenced by industry performance, rather than just by individual corporate performance ${ }^{18}$ Rewarding and punishing executives based on industry performance gives executives strong incentives to refrain from competition that lowers industry profits, even if the horizontal shareholders never directly ask them to do so. Indeed, even if some corporate managers did not know that some of their shareholders also owned shares in their rivals, managers who failed to compete aggressively against their corporation's rivals would tend to do better in corporate elections to the extent those elections are influenced by the votes of investors who are also invested in those rivals.

For that matter, it suffices that institutional investors have incentives to fail to exercise their corporate governance rights in a way that demands maximizing individual corporate performance over industry performance. Consider the case of DuPont, whose main competitor in the seeds market is Monsanto. The top four shareholders of DuPont (Vanguard, BlackRock, State Street, and Capital Research) are also four of the top five shareholders in Monsanto, and they own respectively 19.4\% of DuPont and 19.8\% of Monsanto. ${ }^{19}$ The fifth largest shareholder of DuPont, the Trian Fund, did not own significant shares in Monsanto, and Trian launched a proxy contest criticizing DuPont management for failing to maximize DuPont profits. $^{20}$ In particular, Trian complained that: (1) DuPont profits had risen only because industry profits had risen and that DuPont was not increasing profits relative to its competitors; (2) DuPont was not aggressively investing in R\&D to gain market share; (3) DuPont's CEO sold her DuPont shares and thus lessened her competitive incentives; and (4) DuPont entered into a reverse payment patent settlement with Monsanto whereby, instead of competing, DuPont paid Monsanto for a license to use Monsanto’s patent. ${ }^{21}$

These complaints make perfect sense for nonhorizontal DuPont shareholders who own no shares in its competitors and are thus only interested in maximizing DuPont's profits. But these complaints are much less likely to persuade horizontal

18 See infra Part II.

${ }^{19}$ Martin C. Schmalz, How Passive Funds Prevent Competition (May 18, 2015), available at http://ericposner.com/martin-schmalz-how-passive-funds-prevent-competition/ .

${ }^{20} \mathrm{Id}$.

${ }^{21} I d$. 
shareholders who instead benefit from maximizing the joint profits of DuPont and Monsanto. It was thus unsurprising that Trian's proxy contest was not supported by the four top shareholders of DuPont, given that their 19.8\% share of Monsanto exceeded their $19.4 \%$ share in DuPont and that Monsanto has nearly double the market capitalization of DuPont. ${ }^{22}$ Their failure to support the proxy contest proved decisive because the proxy contest was narrowly defeated. Consistent with the proposition that the proxy contest sought to further DuPont-specific competitive interests rather than the anticompetitive joint interests of both DuPont and Monsanto, the defeat of the proxy contest caused DuPont stock to decline sharply and Monsanto stock to sharply rise. ${ }^{23}$

My analysis will proceed in three steps. First, I begin in Part I by explaining how new empirical evidence on horizontal shareholdings not only indicates pervasive horizontal shareholding that economic models indicate are likely to have anticompetitive effects, but also confirms the predictions of those economic models by empirically proving that horizontal shareholdings have the predicted anticompetitive effects. This new empirical work also provides the only systemic empirical validation we have of the market concentration threshold (an HHI over 2500) that the federal antitrust agencies now use to judge whether a market is concentrated enough to make it likely that a concentration increase would have anticompetitive effects. Roughly speaking, an HHI over 2500 this means that the product market has four major firms or fewer. When the same set of institutional investors has large stockholdings across such a concentrated market, their horizontal shareholdings are likely to be problematic.

Second, I then show, in Part II, that horizontal shareholdings can help explain some fundamental economic puzzles. Horizontal shareholdings help explain the puzzle of why large sophisticated corporate shareholders support executive compensation methods that reward executives more for the success of their industry rather than the relative success of their firm, notwithstanding the persuasive critique by my colleagues Lucian Bebchuk and Jesse Fried that this method does not maximize profits for the individual firm. ${ }^{24}$ Horizontal shareholdings also help explain why, in the recovery from the recent Great Recession, firms that made record high profits because of enormous fiscal and monetary stimulus have proven so reluctant to invest

\section{${ }^{22} I d$.}

$23 \quad$ Id; $\quad$ http://www.usatoday.com/story/money/business/2015/05/13/dupont-proxyfight/27224495/.

${ }^{24}$ Lucian Bebchuk \& Jesse Fried, PAy Without Performance Chpts. 11-12 (2006); Azar, Schmalz \& Tecu, supra note, at 33. 
those high profits on increasing output and employment. Finally, the rise of horizontal shareholdings in recent decades helps explain why, as Thomas Piketty has famously observed, income inequality has risen in those recent decades in a way that reflects greater returns to capital relative to labor. ${ }^{25}$ Antitrust enforcement against horizontal shareholdings in concentrated markets thus offers the promise of improving management compensation, increasing economic growth and employment, and reducing income inequality.

Third, Part III shows that, contrary to the assertion by some that new legislation is required to deal with this new anticompetitive problem, current antitrust law provides ample authority for antitrust agencies and private litigants to attack stock acquisitions that create anticompetitive horizontal shareholdings in concentrated markets. The so-called passive investor exception is not to the contrary. It requires complete passivity in influencing corporate management or governance, not a passive investment strategy. Nor is it really an exception because, when established, all the doctrine really does is heighten the burden of proof. Because the empirical evidence suggests this heightened burden can be met, even truly passive horizontal shareholdings could be subject to antitrust challenge.

\section{THE ANTICOMPETITIVE EFFECTS OF HORIZONTAL SHAREHOLDING}

To determine the likelihood that a merger would be anticompetitive without considering any horizontal shareholding, U.S. antitrust agencies have long measured market concentration by calculating the Herfindal-Hirschman Index, usually called the HHI, and measuring how it would be increased for each market affected by the merger. The HHI equals the sum of the square of each firm's market share, and the change in $\mathrm{HHI}$ (or $\Delta \mathrm{HHI}$ ) is how much the merger would increase HHI. Thus, if two merging firms had a 30\% share each and a third firm had a $40 \%$ share, the HHI before the merger would be $30^{2}+30^{2}+40^{2}=3400$. The HHI after the merger would be $60^{2}+40^{2}=5200$, and thus the $\Delta \mathrm{HHI}$ would be 1800 . Under the U.S. merger guidelines, a merger is presumed likely to have anticompetitive effects if it produces a $\Delta \mathrm{HHI}$ above 200 that results in an HHI above $2500 .{ }^{26}$

A seminal article by Daniel O'Brien and Steven Salop systematized analysis of the anticompetitive incentives of horizontal shareholders by showing they could be

25 Thomas Piketty, Capital In the Twenty-First Century; Eric Posner \& E. Glen Weyl, Mutual Funds' Dark Side, Slate (April 16, 2015).

${ }^{26}$ U.S. DOJ/FTC Horizontal Merger Guidelines § 5.3 (2010). 
captured by modified HHIs (or MHHIs). ${ }^{27}$ O’Brien and Salop established that if HHIs accurately measure the likelihood of anticompetitive effects from completely separate ownership, economic modeling indicated how to calculate MHHIs that measured the likelihood of anticompetitive effects in a way that took into account partial ownership overlaps among horizontal rivals. ${ }^{28}$

An impressive recent empirical study by José Azar, Martin C. Schmalz and Isabel Tecu takes advantage of the fact that, for the airline industry, we have public data on airline prices and quantity by route. For each route they calculate an HHI that ignores horizontal shareholdings, an MHHI that takes horizontal shareholdings into account, and a $\triangle \mathrm{MHHI}$ that equals the difference between MHHI and HHI. ${ }^{29}$ $\Delta \mathrm{MHHI}$ thus provides a good measure of the degree to which market concentration is increased by the stock acquisitions that create horizontal shareholdings. Using this data, they make various major findings.

First, Azar, Schmalz and Tecu calculate that for the average airline route, the HHI has over time ranged from 5000-5400 and $\triangle \mathrm{MHHI}$ has ranged from 1000-2600, resulting in MHHIs ranging from $6000-8000 .{ }^{30}$ Thus, their study proves that horizontal shareholdings are so pervasive that the stock acquisitions that created them produce a resulting MHHI that is more than 2-3 times the guideline's 2500 HHI threshold and a $\Delta$ MHHI that is 5-13 times bigger than the guideline's $200 \Delta \mathrm{HHI}$ threshold. Given that the guidelines presume likely anticompetitive effects from a merger that produces an HHI over 2500 and a $\Delta$ HHI over 200, this means that the

27 O’Brien \& Salop, Competitive Effects of Partial Ownership: Financial Interest and Corporate Control, 67 ANTITRUST L.J. 559 (2000). I focus on O’Brien and Salop because they provide the best developed statement of the theory and method for MHHIs. However, the point that horizontal shareholdings reduce competitive incentives was first made in J. Rotemberg, Financial transaction costs and industrial performance (1984), and MHHIs were first proposed in Timothy Bresnahan \& Steven Salop, Quantifying the competitive effects of production joint ventures, 4(2) INTERNATIONAL JOURNAL OF INDUSTRIAL ORGANIZATION 155 (1986). For other excellent literature developing this idea, see R. H. Gordon, Do publicly traded corporations act in the public interest?, Discussion paper, National Bureau of Economic Research (1990); David Gilo, The Anticompetitive Effect of Passive Investment, 99 Mich. L. REV. 1 (2000); David Gilo, D., Y. Moshe, and Y. Spiegel, Partial cross ownership and tacit collusion, 37(1) RAND JOURNAL OF ECONOMICS 81 (2006); Robert G. Hansen and John R. Lott, Jr., Externalities and Corporate Objectives in a World with Diversified Shareholder/Consumers, 31 J. FIN. \& QUANT. ANALYSIS 43 (1996).

${ }^{28}$ O’Brien \& Salop, supra note, at 597, 610-611.

${ }^{29}$ Azar, Schmalz \& Tecu, supra note, at 11.

${ }^{30}$ Id. at Figure 1; see also id. at 12, $16 .$. 
stock acquisitions that produce an average MHHI of 5000-5400 and average $\Delta \mathrm{MHHI}$ of 1000-2600 should be presumed highly likely to have anticompetitive effects.

Second, Azar, Schmalz and Tecu empirically confirm the validity of MHHI models by running a regression that controls for differences among routes, carriers, and time periods, showing that higher levels of $\Delta \mathrm{MHHI}$ (i.e., greater horizontal shareholdings) increased prices with a $99.9 \%$ level of statistical confidence. ${ }^{31}$ Given the actual levels of HHIs and MHHIs, they show that this effect means that in the average airline route, prices are 3-5\% higher than they would be without any horizontal shareholdings. ${ }^{32}$ This is bigger than it sounds for two reasons. First, 3$5 \%$ is two to three times the average profit margin in the airline industry. ${ }^{33}$ Second, this 3-5\% increase in prices is the average across all airline routes, some of which were too unconcentrated for the horizontal shareholdings to matter. The effect is much higher $(6.7 \%)$ in the routes where horizontal shareholding produces very high market concentration. ${ }^{34}$

This price correlation cannot be explained by the alternative hypothesis that maybe institutional investors are good at choosing to invest in firms that fly in routes with increasing demand. That alternative hypothesis conflicts with the evidence that higher levels of $\Delta \mathrm{MHHI}$ also decrease quantity with a $99.9 \%$ level of statistical confidence, with the average quantity decrease across all routes being $6 \%$, which matches prior demand elasticity estimates of the extent to which increasing airline prices decreases market output. ${ }^{35}$ That alternative hypothesis also conflicts with the facts that these institutional investors generally pursue passive investment strategies like indexing and are making investments in airlines that have hundreds of different routes, only some of which have the significant HHIs and $\Delta \mathrm{MHHI}$ that produce the observed price effects.

Third, to address any possible reverse causality or endogeneity problem, Azar, Schmalz and Tecu also do an econometric analysis of BlackRock's acquisition of Barclays Global Investors. Because this acquisition was driven by Barclays' decision to sell its iShares family of exchange-traded funds, and because airline stocks are a small share of the portfolio of these institutional investors, any effect this acquisition had on airline ticket pricing seems clearly exogenous. ${ }^{36}$ Azar,
${ }^{31}$ Id. at 3, 18.
${ }^{32} I d$. at 3, 19-20.
${ }^{33} \mathrm{Id}$. at 3.
${ }^{34} \mathrm{Id}$. at 19.
${ }^{35}$ Id. at 3, 27-28 \& Online Appendix Table F.1
${ }^{36}$ Id. at 3, 21. 
Schmalz and Tecu showed that the BlackRock-Barclays combination of institutional investors increased airline prices on routes affected by the combination, compared to unaffected routes, using a regression that controlled not only for local economic conditions but also for differences across each route and carrier. ${ }^{37}$ They further show that the coefficient produced by this regression indicates that horizontal shareholdings increase average airline prices by $10 \%{ }^{38}$ Thus, this strict control for endogeneity results in an estimated price effect that is even greater than the $3-5 \%$ estimated in the regression mentioned above.

Fourth, Azar, Schmalz and Tecu show that the effect of horizontal shareholdings (i.e., $\Delta \mathrm{MHHI}$ ) on prices becomes significant only when base market HHI concentration exceeds $2500 .{ }^{39}$ This finding is important because although there have been many empirical studies of mergers, we have not yet really had one that rigorously tested the HHI threshold levels used by the agencies. This study indicates that the 2500 threshold that the agencies use does indeed accurately determine likely anticompetitive effects. The study thus validates the agencies' decision in 2010 to raise the HHI threshold from 1800 to 2500 to determine when a market is highly concentrated enough that increased concentration levels are likely to cause anticompetitive effects. ${ }^{40}$

In short, horizontal shareholdings are so pervasive that guidelines and economic models indicate they are highly likely to increase airline prices in concentrated markets. Further, empirical analysis indicates that having substantial horizontal shareholdings actually does raise prices significantly when the owned firms compete in concentrated markets, meaning a market with an HHI above 2500. An HHI over 2500 means, roughly speaking, there are four or fewer major firms in the market.

There is good reason to think similar levels of horizontal shareholdings exist in other industries because institutional investors own $80 \%$ of all stock in S\&P 500 corporations, which is actually a bit greater than the $77 \%$ of airline stock that is owned by institutional investors. ${ }^{41}$ The major likely exception is markets with foreign firms who are more likely to have significantly different investors. Leaving aside that exception, horizontal shareholdings similar to the airline industry are

${ }^{37}$ Id. at 3-4, 25.

${ }^{38} \mathrm{Id}$. at 4.25.

39 Id. at 29.

${ }^{40}$ Compare U.S. DOJ/FTC Horizontal Merger Guidelines $§ 5.3$ (2010) (highly concentrated market threshold of 2500) with U.S. DOJ/FTC Horizontal Merger Guidelines § 1.5 .1 (1992) (highly concentrated market threshold of 1800).

${ }^{41}$ See supra Introduction. 
likely to exist in other industries and thus are likely to create anticompetitive effects if the relevant product markets are sufficiently concentrated.

The next section shows that horizontal shareholdings also illuminate some other economic puzzles relevant to corporate governance and national economic policy.

\section{How Horizontal SHAREHOLdINGS ILLUMinAte SOME FundAMENTAL ECONOMIC PUZZLES}

The economic effects of horizontal shareholdings are interesting not just as a matter of antitrust policy, but as a matter of corporate and economic policy more generally. In particular, horizontal shareholdings can help explain fundamental puzzles about executive compensation, macroeconomic policy, and economic inequality.

\section{A. Executive Compensation Based on Industry Performance Rather than Corporate Performance}

As my colleagues Lucian Bebchuk and Jesse Fried have persuasively shown, corporations generally compensate executives using measures (like stock options) that are $70 \%$ driven by general market profitability and only $30 \%$ driven by individual corporate performance. ${ }^{42}$ They argue that this method of compensation provides executives with a windfall that is unrelated to executive performance and thus harmful to corporate shareholders. To correct this, they advocate that shareholders adopt various methods to design stock options to screen out marketwide effects, such as allowing stock options to be exercised only if the executive's firm exceeds marketwide performance or indexing the option's exercise price to move with marketwide changes so that the profits from the options reflect the extent to which executives have outperformed the market. ${ }^{43}$ As they note, scholars have deemed it puzzling that corporations have in fact failed to adopt such methods. ${ }^{44}$ Their explanation is that managerial power is blocking the adoption of methods of executive compensation that would benefit shareholders. ${ }^{45}$

However, their managerial power explanation raises a further puzzle. If these methods of executive compensation reflect managers using their power against

\footnotetext{
42 BEBCHUK \& FRIED, supra note, at 138-139.

${ }^{43}$ Id. at $140-143$.

${ }^{44} \mathrm{Id}$. at 143.

${ }^{45}$ Id. at $144-146$.
} 
shareholder interests, why is that large institutional shareholders usually fail to vote both for shareholder proposals to change these methods and against re-electing boards who refuse to change them? After all, institutional investors should know better, and they have large enough stakes to act on their knowledge. The managerial power explanation seems incomplete.

Moreover, if increasing executive pay to benefit managers were the only explanation, why is it that, from 1993 to 2009, decisions to oust management are driven almost as much by the performance of their industry as by the performance of their firms? ${ }^{46}$ When a corporation ousts a manager, that manager's power has clearly been overcome. So in these cases, when shareholders have overcome the incumbency power of management, it does not make much sense that the shareholders would chose to exercise their removal power based on a performance measure that does not reflect the shareholders' own interests. Further, contrary to the managerial power explanation, the use of industry performance evaluation for ouster decisions turns out not to vary with the length of executive tenure or degree of executive power. ${ }^{47}$

The study by Azar, Schmalz and Tecu offers a different explanation: the use of industry performance measures is not a bug but a feature for institutional investors who are invested across the industry. ${ }^{48}$ For such institutional investors, managers who increase individual corporate performance by competing with rivals and taking away market share decrease institutional investor profits across the industry by decreasing industry profits. Institutional investors are more likely to prefer managers who maximize industry profits by avoiding competition.

To be sure, there are other alternative explanations for why corporations might assess executives based on industry performance. One is that shareholders make an attribution error: mistakenly blaming managers for low profits regardless of whether it is their fault. ${ }^{49}$ But it seems implausible that institutional investors are that unsophisticated. Another alternative explanation is that economic downturns expose managerial skill deficits that were otherwise unobservable, but this explanation conflicts with the fact that judging management based on industry performance is

46 Jenter, Dirk and Kanaan, Fadi, CEO Turnover and Relative Performance Evaluation at 12 (April 15, 2014). Stanford University Graduate School of Business Research Paper No. 1992; MIT Sloan Research Paper No. 4594-06; Rock Center for Corporate Governance Working Paper No. 24. Available at SSRN: http://ssrn.com/abstract=885531 or http://dx.doi.org/10.2139/ssrn.885531

${ }^{47}$ Id. at 2-4, 18-19.

${ }^{48}$ Azar, Schmalz \& Tecu, supra note , at 33-34.

${ }^{49}$ Jenter \& Kanaan, supra note, at 2-3. 
just as high for longer-tenured managers, who are more likely to have already proved their skills in good and bad economic times. ${ }^{50}$ Moreover, both alternative explanations seem inconsistent with the fact that ouster decisions are dominated by industry performance, rather than by general stock market performance. ${ }^{51}$ That fact is more consistent with the anticompetitive explanation.

The anticompetitive explanation also fits with the fact that up until the 1980s, the empirical data indicated that managers were ousted based on individual corporate performance, with industry performance filtered out of dismissal decisions. ${ }^{52}$ The change to making dismissal decisions based on industry performance since then coincides with the increasing share of stock held by institutional investors, which has grown from $34 \%$ of all stock in 1980 to $67 \%$ of all stock in $2010 .^{53}$ Likewise, stock options became an important method of management compensation only in the $1990 \mathrm{~s},{ }^{54}$ which again coincides with the increasing influence of institutional investors who have affirmative incentives to favor methods of executive compensation that reward industry performance. The alternative explanations do not explain these changes over time because increasing institutional shareholder power should lower both managerial power and the likelihood that shareholders believe in unsophisticated performance metrics, and because the possibility that different managers are appropriate during economic downturns seems no more true since the 1980s than it was before.

This is not to deny that managerial power might also often explain the use of compensation methods that give managers windfalls for industry performance. As

${ }^{50} \mathrm{Id}$. at 2.

${ }^{51} \mathrm{Id}$. at at 1, 13-14. Jenter and Kanaan themselves dismiss the anticompetitive explanation, which they call the oligopolistic explanation, because the effect of industry performance on management dismissals persists for small firms and with broader industry definitions. Id. at 3, 1516. But neither of those measures is telling. Small firms can be mavericks that could undercut industry pricing, and institutional investors have even more incentives to rein in the competitive pricing of small firms because the institutional investors will earn more profits from the larger firms in the same business market. Further, $\triangle \mathrm{MHHI}$ could be high even for small firms or for broad industry definitions. Even to the extent $\Delta \mathrm{MHHI}$ were not high in such cases, these findings would only show that horizontal shareholdings are not the sole explanation for why managers are evaluated based on industry performance; that would not disprove the anticompetitive explanation in other cases.

52 Jenter \& Kanaan, supra note, at 4-5.

${ }^{53}$ Marshall E. Blume \& Donald B. Keim, Institutional Investors and Stock Market Liquidity: Trends and Relationships at 5 (August 21, 2012), available at SSRN: http://ssrn.com/abstract=2147757.

\footnotetext{
${ }^{54}$ BEBCHUK \& FRIED, supra note, at 137.
} 
Bebchuk and Fried point out, we also see stock options that reward managers for industry performance even for corporations in unconcentrated product markets, where the anticompetitive explanation is likely weak. ${ }^{55}$ But the empirical evidence described above indicates that the anticompetitive explanation is also important, and perhaps more important in explaining the overall trend. The full public policy argument against allowing managers to be compensated based on industry performance must rest on a combination of these two explanations. Either the corporation is dominated by management, in which case such compensation methods likely reflect managerial power at the expense of shareholders, or the corporation has strong shareholders, in which case such compensation methods likely reflect the anticompetitive incentives of horizontal shareholders to favor industry profits over individual firm profits. Neither would be in the public interest.

\section{B. Explaining the Failure of High Corporate Profits to Lead to High Growth}

Another big recent economic puzzle in recent years has been why, at a time when corporate profits have been at record highs, corporations have been so reluctant to invest those profits on expanding output. Ordinarily, high profits induce corporations to invest in expansion to try to get a greater share of those high profits, and that expansion in turns leads to high levels of economic growth and employment. Recently corporate profits have risen to record levels, nearly $\$ 2$ trillion dollars per year, four times the corporate profits in the late 1990s and higher as a percentage of GDP than any time in the last sixty years. ${ }^{56}$ But despite that spending, U.S. corporate investments in expansion and capital projects have fallen; indeed, as a percentage of GDP, corporate investments were nearly $50 \%$ higher in the late 1990 s than now. ${ }^{57}$ Instead of spending to expand output, corporations have retained between $\$ 3.5$

${ }^{55}$ BEBCHUK \& FRIED, supra note, at 154.

${ }^{56}$ See Harlan Green, Why Lower Growth, Higher Corporate Profits?, HufFInGTON Post (Jun 24, 2015), available at http://www.huffingtonpost.com/harlan-green/why-lower-growth-higherc_b_7656672.html; Jordan Weissmann, The Economy Stinks, but at Least Corporate Profits Are at 60-Year Highs!, THE ATLANTIC (July 27, 2012), available at http://www.theatlantic.com/business/archive/2012/07/the-economy-stinks-but-at-least-corporateprofits-are-at-60-year-highs/260411/.

${ }^{57}$ Green, supra note ; Paul Krugman, The Profits-Investment Disconnect, NEW YoRK TIMES BLOG (Oct 24, 2014), available at http://krugman.blogs.nytimes.com/2014/10/24/the-profitsinvestment-

disconnect/?module=Search\&mabReward=relbias\%3As\%2C $\{\% 221 \% 22 \% 3 \mathrm{~A} \% 22 \mathrm{RI} \% 3 \mathrm{~A} 5 \% 22\}$ $\underline{\text { \& } \mathrm{r}=1}$. 
trillion and \$5 trillion dollars in cash and spent other profits on stock buybacks, dividend payments, and high executive compensation. ${ }^{58}$

To be sure, the United States has managed to return to sluggish growth since the Great Recession. But only at the cost of massive deficit spending that has increased our national debt by $\$ 9$ trillion since 2008 and massive monetary stimulus that has not only set short-term interest rates at zero percent for years but involved quantitative easing that effectively involved printing money to purchase $\$ 4.5$ trillion in long-term securities. ${ }^{59}$ In a nation of 320 million, this $\$ 13.5$ trillion stimulus exceeds $\$ 42,000$ per person even if one puts aside the fact that short-term interest rates have been set at zero. But even with this massive fiscal and monetary stimulus, the labor force participation rate has dropped from $65.8 \%$ in 2009 to $62.6 \%$ now, which is the lowest it has been since $1977 .{ }^{60}$ The unemployment rate has fallen, but that reflects the fact that fewer people in the labor force looking for work, which is quite rational given that there are fewer good jobs available than there should be. Further, the labor share of income is now at historically low levels. ${ }^{61}$ For some reason, while all this stimulus has produced high corporate profits, it has not produced the expected level of business expansion that would seriously increase employment levels and wages.

As Paul Krugman has observed, "this kind of divergence - in which high profits don't signal high returns to investment - is what you'd expect if a lot of those profits reflect monopoly power rather than returns on capital." 62 But what would that unexpected exercise of monopoly power be? After, all we have antitrust laws that are actively enforced by government agencies and private actors to curb anticompetitive creations of market power.

Perhaps the explanation is that we now have pervasive horizontal shareholdings because more and more stock is in the hands of institutional investors but we have, so far, had virtually no antitrust enforcement against it because the anticompetitive

${ }_{59}^{58}$ Green, supra note .

See

http://www.treasurydirect.gov/NP/debt/search?startMonth=12\&startDay=01\&startYear=2007\&e ndMonth=07\&endDay=06\&endYear=2015; Justin Wolfers, The Fed Has Not Stopped Trying to Stimulate the Economy, NEW YORK TIMES BLOG (Oct 29, 2014), available at http://www.nytimes.com/2014/10/30/upshot/the-fed-has-not-stopped-trying-to-stimulate-theeconomy.html?rref=upshot\&abt $=0002 \& a b g=1$

${ }^{60}$ See http://data.bls.gov/pdq/SurveyOutputServlet .

${ }^{61}$ https://research.stlouisfed.org/fred2/series/PRS85006173.

62 Krugman, supra note . 
problem was until recently unappreciated. ${ }^{63}$ With such horizontal shareholdings, firms acting in the interests of their shareholders have incentives to constrain output rather than expand. The high profits they reap are not a signal to competitively expand individual firm output. The high profits are, rather, a symptom of the fact that they have successfully constrained overall market output. This could help explain why high corporate profits have not led to expansion and higher economic growth and employment levels.

To be sure, one might doubt that anticompetitive conduct could have such large macroeconomic effects. But the Azar, Schmalz and Tecu study suggests that horizontal shareholdings have lowered output by $6 \%$ in at least one industry. ${ }^{64}$ If generalizable to other industries, which seems plausible give that institutional investors have an even greater share of large corporate stock in other industries, this finding suggests that eliminating horizontal shareholdings could increase economic output by $6 \%$, which would have a huge effect on economic growth and employment levels.

Moreover, there is precedent for anticompetitive conduct having these sorts of large macroeconomic effects and for antitrust enforcement to thus have strong macroeconomic benefits. Antitrust enforcement was a key part of what brought us out of the Great Depression. To be sure, conventional wisdom is that World War II is what brought us out of the Great Depression. But while wartime spending certainly led to expansion in the 1940s, our recovery out of the Great Depression actually began in 1938 and cut unemployment in half by 1941, which clearly preceded our December 1941 entry into World War II. ${ }^{65}$ Nor can pre-war military buildup explain the recovery because average defense spending in 1938 actually dropped $18.5 \%$ and continued to be $12 \%$ below 1937 levels in 1939 and $9.5 \%$ below

63 There have been some challenges to mergers of investors that left a single investor group with substantial enough horizontal shareholdings in competitors to lessen competition between them. See https://www.ftc.gov/enforcement/cases-proceedings/0610197/tc-group-llc-riverstoneholdings-llc-carlyleriverstone-global. However, so far there seem to have been no challenges to stock acquisitions that left multiple investors with substantial horizontal shareholdings that in aggregate lessen competition.

${ }^{64}$ See Azar, Schmalz \& Tecu, supra note, at 3, 27-28 \& Online Appendix Table F.1.

65 See infra at _; François R, Velde, The recession of 1937-A cautionary tale, EconOMIC Perspectives 16, 17, 33 (4Q 2009). 
1937 levels in $1940 .{ }^{66}$ Military stimulus thus cannot explain the recovery that began in 1938 because that recovery actually had to overcome military spending cuts.

Others assume that what caused the recovery that began in 1938 is the fact that the U.S. adopted looser monetary and fiscal policies in 1938. But this theory has two problems. First, statistical analysis shows that, while monetary and fiscal policy helped, they cannot explain the full strength of the ensuing recovery. ${ }^{67}$ Thus, some factor other than monetary and fiscal policy is needed to explain why the economy "rebounded so strongly" from 1938-41. ${ }^{68}$ Second, prices actually declined from 1938 to 1941, with only one short deviation in September 1939, when Hitler's invasion of Poland led to speculative buying. ${ }^{69}$ But even then prices remained below 1938 levels and continued their decline after that 1939 spike. $^{70}$ This downward price trend is precisely the opposite of the price inflation one would expect if looser monetary and fiscal policy were what drove the recovery that began in $1938 .{ }^{71}$

Increased antitrust enforcement is the missing factor that explains why the 1938-41 recovery was not only so strong, but also lowered prices. Although the Sherman Act was enacted in 1890, antitrust enforcement was rare until 1938 and anticompetitive conduct was common. ${ }^{72}$ President Theodore Roosevelt made many political speeches about being a trustbuster, but he brought few antitrust cases. Indeed, his entire Antitrust Division had only five lawyers. ${ }^{73}$ By the time his cousin President Franklin Delano Roosevelt took office in 1933, the Antitrust Division had expanded slowly to 15 lawyers, but that was hardly enough for vigorous enforcement in a nation of over 130 million people. ${ }^{74}$

66 These figures are based on defense spending as a percentage of GDP. http://www.usgovernmentspending.com/spending_chart_1937_1942USp_16s1li011tcn_30f_20th _Century_Defense_Spending\#copypaste

${ }^{67}$ Velde, supra note, at 33.

${ }^{68}$ Id.; James B. Stewart, Aftershock to Economy Has a Precedent That Holds Lessons, N.Y. Times (Aug. 12, 2011).

${ }^{69}$ Velde, supra note, at 29.

${ }^{70} \mathrm{Id}$.

${ }^{71} I d$. at 26 (describing the price decline during this recovery as puzzling).

72 Thurman Arnold, Antitrust Law Enforcement, Past and Future, 7 LAW AND CONTEMPORARY PROBLEMS 5, 12 (1940) ("After a period of fifty years of only occasional enforcement, violations of the antitrust laws have become so common as to cause no comment. Lawyers in many communities have been scarcely aware of their existence. They have not been a problem considered in making business deals."); id. at 15 (noting that "thousands of price fixing agreements and instances of coercion of small businesses” went unprosecuted).

${ }^{73} \mathrm{Id}$. at 9.

${ }^{74}$ Id. 
Worse, from 1933 to 1938, the Roosevelt administration fell prey to the natural, but mistaken, tendency to confuse the symptoms of the Depression (low prices and profits) with the disease (low production and employment). To beef up prices and profits, the administration not only relaxed antitrust enforcement, but in 1933 affirmatively allowed cartels via the National Industrial Recovery Act (NIRA). ${ }^{75}$ The effect was to significantly raise prices. For example, from April 1933 to June 1934, prices for bituminous coal (which was cartelized under the Act) rose 20\%, while prices for anthracite coal (which was not) dropped $7 \%{ }^{76}$ The NIRA exacerbated the Depression because higher prices meant consumers bought less, which reduced production and thus reduced employment, which in turn reduced the ability of consumers to buy, further reducing production and employment. NIRA cartels lowered investment by $60 \%$, employment by $11 \%$, and output by $13 \%$, causing about $60 \%$ of the post- 1933 depression in national output. ${ }^{77}$ Even after the NIRA was held unconstitutional in $1935,{ }^{78}$ the mistaken economic intuition that underlay it continued to produce limited antitrust enforcement. ${ }^{79}$

That abruptly changed in March 1938, when President Roosevelt appointed Yale Law Professor Thurman Arnold to head the Antitrust Division. Arnold explicitly rejected the notion that antitrust enforcement should be relaxed during an economic downturn. ${ }^{80}$ He vastly increased antitrust enforcement, expanding the antitrust

75 Act of June 16, 1933, c. 90, 48 Stat. 195, 196; 15 U.S.C. § 703; ElLis W. HAWLEY, The New Deal And The Problem Of Monopoly 59-61 (1995)(noting that under the NIRA, 444 industries fixed prices, 61 limited output, and 30 restricted capacity).

${ }^{76}$ Harold L. Cole \& Lee E. Ohanian, New Deal Policies and the Persistence of the Great Depression: A General Equilibrium Analysis, 112 Journal OF POLITICAL ECONOMY 779, 790-92 (2004).

77 Id. at 781, 810; see also Jason E. Taylor, The Output Effects of Government Sponsored Cartels During the New Deal, 50 J. InDUS. ECON. 1, 8 (2002) (finding that NIRA cartels lowered manufacturing output by $10 \%$ even if separates out the fact that the NIRA also fixed wages).

${ }^{78}$ A.L.A. Schechter Poultry Corp. V. United States, 295 U.S. 496 (1935).

${ }^{79}$ Cole \& Ohanian, supra note, at 783, 786; HAWLEY, supra note , at 166, 364. Thurman Arnold's predecessor as head of the Antitrust Division, Robert Jackson, was an illustrious lawyer and went on to become an even more illustrious Supreme Court Justice, but he not a believer in antitrust enforcement because he believed in the theory of the NIRA. Wilson D. Miscamble, Thurman Arnold Goes to Washington: A Look at Antitrust Policy in the Later New Deal, 56 BUSINESS HISTORY REVIEW 1, 13-14 (1982).

${ }^{80}$ Thurman Arnold, Fair and Effective Use of Present Antitrust Procedure, 47 Yale L.J. 1294, 1296-1297 (1938). 
division to 583 lawyers by $1942 .{ }^{81}$ In his five years in office, he brought $44 \%$ of all the antitrust cases that had been brought in the first 53 years of the antitrust laws. ${ }^{82}$

Arnold also made antitrust enforcement far more systematic and focused. Prior enforcement (even before the New Deal) had been not only isolated but also mercurial in a way that often seemed to challenge big businesses just for being big. ${ }^{83}$ The combination meant little deterrence of anticompetitive conduct not only because enforcement was unlikely, but also because it was unclear just what firms were supposed to do to avoid enforcement. Arnold brought intellectual clarity to the task, making clear that (unlike his predecessors) he had no problem with businesses being big as long as their conduct was efficient and lowered consumer prices. ${ }^{84}$ This gave firms a far clearer and more desirable signal about how to modify their behavior. Further, Arnold deliberately used antitrust enforcement as a form of economic policy, targeting industries that he thought were inefficient in a way that hampering economic growth and using multiple simultaneous lawsuits in each selected industry to thoroughly restore free competition at each stage of the industrial process. ${ }^{85}$ His strategy was to "hit hard, hit everyone and hit them all at once." ${ }^{\prime 6}$ He multiplied the effect of his expansion of prosecutorial resources by using prosecutions to obtain extensive consent decrees designed to go beyond the alleged antitrust violations to

${ }^{81}$ See Corwin D. Edwards, Thurman Arnold and the Antitrust Laws, 58 PoL. SCI. Q. 338, 339 n.1 (1943).

${ }^{82} \mathrm{Id}$. at 339.

${ }^{83}$ Gene M. Gressley, Thurman Arnold, Antitrust, and the New Deal, 38 BusinEss History REVIEW 214, 223 (1964).

84 See Thurman W. Arnold, The Bottlenecks Of Business 3-4 (1940) ("Most of the books in the past on the antitrust laws have been written with the idea that they are designed to eliminate the evil of bigness. What ought to be emphasized is not the evil of size but the evils of industries which are not efficient or do not pass efficiency on to consumers."')(emphasis in original); Thurman Arnold, The Policy of Government, supra note , at 58-59; Arnold, Antitrust Law Enforcement, supra note , at 11, 14; Alan Brinkley, The Antimonopoly Ideal and the Liberal State: The Case of Thurman Arnold, 80 ThE JournAL OF AMERICAN HISTORY 557, 567-568, 570571 (1993); 11; Gressley, supra note at 229-230.

${ }^{85}$ See Arnold, Antitrust Law Enforcement, supra note , at 17; Thurman Arnold, The Policy of Government toward Big Business, 18(2) ProceEdings of the ACAdemy Of Political Science 58, 62-63 (1939); Brinkley, supra note , at 565-566; Miscamble, supra note at 11; Gressley, supra note at 224.

86 ARnOLD, BotTleneCKs, supra note, at 191-93; Joseph Alsop \& Robert Kintner, Trust Buster: The Folklore of Thurman Arnold, SATURDAY EvEnING Post at 7 (Aug. 12, 1939); Brinkley, supra note , at 565; Miscamble, supra note at 11; Gressley, supra note at 224. 
make markets as competitive as possible, as quickly as possible, in as many industries as possible. ${ }^{87}$

Arnold himself stated that his goal was to lower prices that were elevated by anticompetitive conduct so that consumers could buy more, which would cause firms to increase production and thus employment, which in turn would increase consumer purchasing power, further increasing production and employment. ${ }^{88}$ His antitrust enforcement successfully lowered prices in the targeted industries. ${ }^{89}$ This antitrust enforcement can thus explain, unlike fiscal and monetary policy, why prices declined during the economic expansion of 1938-41. It also provides the missing factor that explains the remarkable strength of that recovery.

After dropping 32\% from 1937 to 1938, industrial production rose by an average of 22\% per year after Arnold's 1938 appointment. ${ }^{90}$ In order to produce more, firms needed to hire more workers. Unemployment, which had risen from $14 \%$ to $19 \%$ from 1937 to 1938, steadily declined after Arnold's appointment, reaching 10\% by 1941, as the following chart illustrates. ${ }^{91}$

87 See ARNOLD, BotTlEnECKS, supra note , at 141-44, 152-163 (1940); Brinkley, supra note , at 565; Gressley, supra note at 222-223.

${ }^{88}$ See Thurman Arnold, Antitrust Div., Report Of Assistant AtTorney General, 12, 44-45 (1939); Arnold, Antitrust Law Enforcement, supra note , at 5-6, 8; Brinkley, supra note , at 571; HAWLEY, supra note, at 411.

${ }^{89}$ ARnOLD, BotTlEnECKS, supra note , at 48, 77; HAWLEY, supra note , at 436, 439.

${ }^{90}$ Velde, supra note , at 17, 34.

${ }^{91}$ http://www.u-s-history.com/pages/h1528.html 


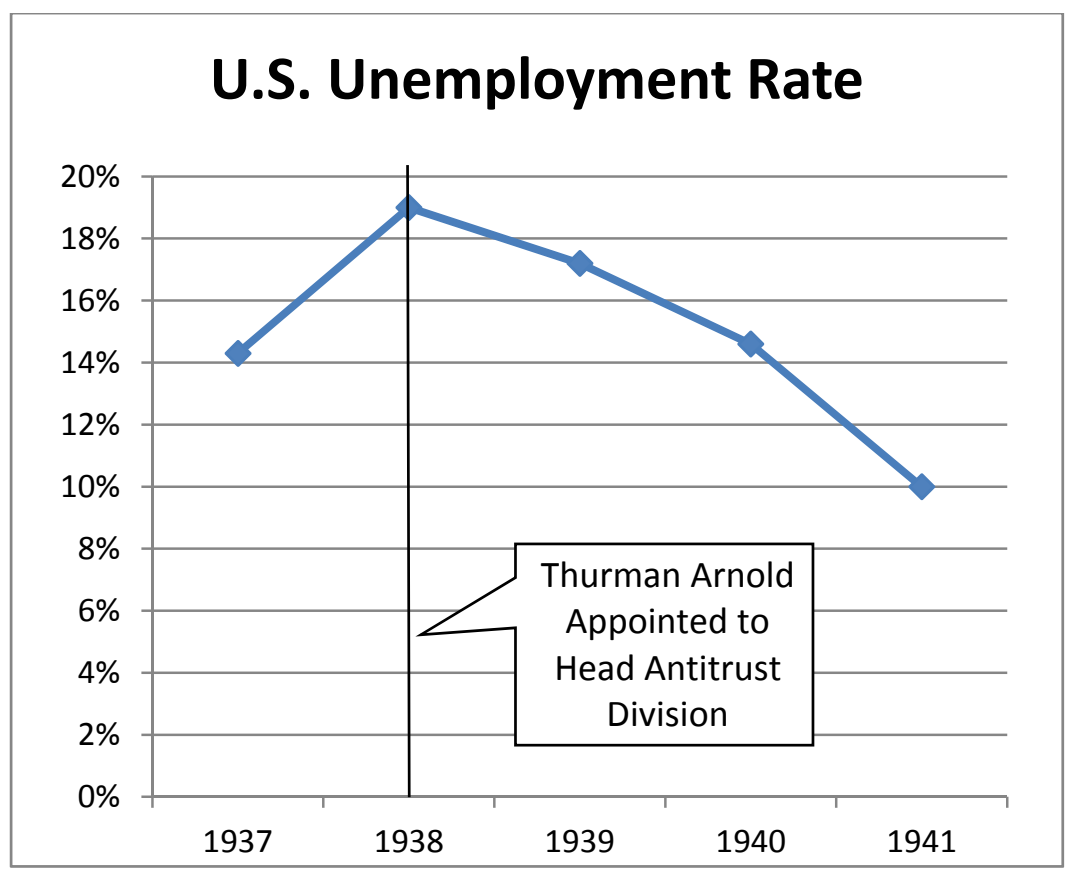

Thus, while other factors surely contributed, the evidence indicates that increased antitrust enforcement played a key role in bringing us out of the Great Depression. It is unclear whether the effects of antitrust enforcement against horizontal shareholdings would be similarly large today in improving our recovery from the Great Recession. On the one hand, the anticompetitive effects of horizontal shareholdings are generally weaker than the anticompetitive effects of the sorts of cartels that Arnold attacked. On the other hand, given that institutional investors now own $80 \%$ of all large corporations' stock, horizontal shareholdings are more pervasive across our economy now than cartels were in $1938,{ }^{92}$ and while there was some antitrust enforcement against cartels before 1938, current enforcement against horizontal shareholdings is virtually nonexistent. ${ }^{93}$ Initiating antitrust enforcement against anticompetitive horizontal shareholdings could thus have stronger or weaker effects than Arnold's 1938 expansion of antitrust enforcement. Either way, the economic effects of attacking anticompetitive horizontal shareholdings certainly seem salutary and likely to be significant for the national economy.

92 See Arnold, Fair and Effective Use, supra note, at 1295 (noting that the great mass of markets were competitive even though anticompetitive conduct was common); Arnold, Antitrust Law Enforcement, supra note, at 5-6, 12-13, 15 (same).

93 See supra note 


\section{Explaining the Recent Rise in Economic Inequality}

In his recent bestselling book, Capital in the Twenty-First Century, Thomas Piketty has documented a recent rise in economic inequality that he attributes to the fact that the returns to capital have risen relative to the returns to labor. ${ }^{94}$ Piketty does not show that rising economic inequality is an inherent feature of capitalism. Rather, he shows that income inequality in the U.S. rose from 1900 to 1940, dropped sharply after 1940 and stayed low until 1980, and has since been rising to return to pre-1940 levels. ${ }^{95}$ The puzzle is: what drives these changes in economic inequality over time?

Eric Posner and Glen Weyl argue that Azar, Schmalz \& Tecu's study could explain what has driven the recent rise in economic inequality. ${ }^{96}$ As they point out, the rise in economic inequality since 1980 corresponds to a period when institutional investors' share of corporate stock grew to record levels. They also argue that the earlier period of high economic inequality corresponds to the dominance of anticompetitive trusts in the late 1800s before the Sherman Act was enacted in $1890 .{ }^{97}$ The timing does not quite work for this latter point because Piketty actually shows income inequality rose from 1900 to 1940. But we can still relate the trend in income inequality to anticompetitive conduct because, as I detailed in the prior Section, antitrust enforcement was weak and mercurial until the appointment of Thurman Arnold in 1938, which vastly expanded antitrust enforcement and systematized it to focus on eliminating market inefficiencies. ${ }^{98}$ Before 1938, anticompetitive conduct was thus common. ${ }^{99}$ With this adjustment to their timing, Posner and Weyl's point remains valid that the periods of high U.S. economic inequality correspond to periods when either anticompetitive conduct or anticompetitive horizontal shareholdings were prevalent, whereas the period of low economic inequality corresponds to a period when both were less prevalent. The following figure illustrates the point using Piketty and Saez's measure of economic inequality over time.

\footnotetext{
${ }^{94}$ PIKETTY, supra note, at _ text accompanying Figure I.2.

${ }^{95} \mathrm{Id}$. at Figure I.1, 9.8.

${ }^{96}$ Posner \& Weyl, supra note .

${ }^{97}$ Id.

${ }^{98}$ See supra II.C.

99 See supra II.C
} 


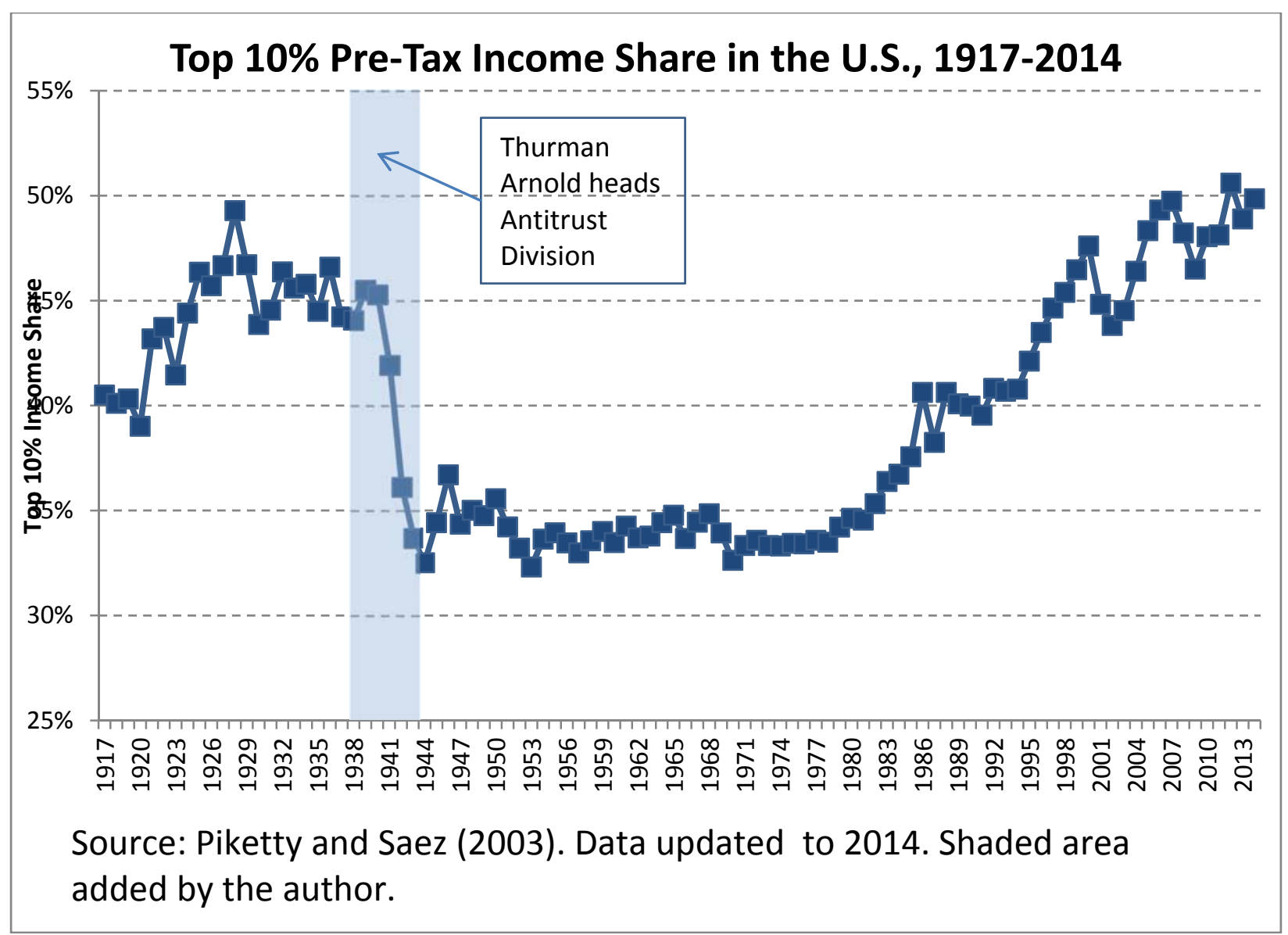

This anticompetitive explanation provides a persuasive mechanism for changes in economic inequality. When markets are anticompetitive, the returns to capital rise because that capital is invested in firms whose product prices are inflated. Anticompetitive markets also lowers the effective returns to labor not only because that same rise in product prices lowers the purchasing power of wages, but also because concentrated markets are more likely to exercise monopsony power over labor rates. Because richer people have more invested in the stock market than those who are less wealthy, the fact that anticompetitive conduct increases returns to capital relative to returns to labor will increase economic inequality. Moreover, executives at corporations earning anticompetitive profits are more likely to be compensated highly, increasing economic inequality within the labor market as well.

Although not addressed by Posner and Weyl, the anticompetitive explanation is also consistent with data on per capita output growth. U.S output grew annually by $1.4 \%$ before 1950, by $2.0 \%$ between 1950 and 1980, and had dropped back to $1.3 \%$ since $1980 .{ }^{100}$ This fits the anticompetitive theory because anticompetitive cartels and

${ }^{100}$ PIKETTY, supra note, at Table 2.5. 
horizontal shareholders can be expected to suppress market output. In contrast, it provides a poor fit with the alternative theory that income inequality rises when the rich become more productive, because if that were so then we should see market output rise with increasing income inequality.

This does not necessarily prove that increasing horizontal shareholdings are the sole or main explanation for the recent rise in economic inequality. Piketty himself argues that historically capitalism has always produced a return to capital that exceeds the national growth rate and that this divergence always increases economic inequality unless offset by wars or taxes or fiscal policy, leading him to conclude that wars and changes in taxes or fiscal policy provide the main explanation for changes in economic inequality over time. ${ }^{101}$ However, it is also true that anticompetitive conduct was permissible for most of human history, which could help explain a historical combination of high returns to capital coupled with lower growth rates. ${ }^{102}$

Moreover, recent work by Matthew Rognlie questions whether the net capital share has consistently grown in the way that Piketty suggests. ${ }^{103}$ Rognlie makes three major points. First, he stresses that after 1948 the net capital share dropped through the 1970s and only then started to rise. ${ }^{104}$ That parallels my above point about the pattern, though his point is limited to the period after 1948 because his data does not extend before then. Second, he argues that Piketty's claim for an overall rise over time comes from an increase in capital returns on housing sector, which in turn relies on the debatable premise that the imputed rent from owner-occupied housing is purely capital income that requires no labor. ${ }^{105}$ Third, Rognlie points out that for

${ }^{101}$ PIKETTY, supra note , at _ (TAN 35), 354-358, Figures 10.9-10.11, 571-575.

102 Piketty also points out that income inequality in Europe has followed a similar trend to the United States. Id. at Figure 9.8. But this is hard to disentangle from U.S. antitrust enforcement because when World War II started, U.S. antitrust enforcers attacked international cartels, Jason Scott Smith, What Did Happen to the Antitrust Movement?, 30 REVIEWS IN AMERICAN HiSTORY 639, 640-642 (2002), and after World War II antitrust experts who had served under Thurman Arnold in the U.S. Antitrust Division "became important players in the postwar reconstruction of the German and Japanese economies, working to contain and eliminate collusion among firms. Through their efforts, Arnold's proteges shaped the economic and political terrain of competition for American and foreign companies in such industries as chemicals, oil, and steel.” Id. at 640, 642-643.

103 Matthew Rognlie, Deciphering the fall and rise in the net capital share (March 2015), available at http://www.brookings.edu/about/projects/bpea/papers/2015/land-prices-evolutioncapitals-share .

${ }^{104}$ Id. at 1, 3, 9.

${ }^{105} I d$. at $1,3,10-11$. 
non-housing capital income, the U-shaped pattern turns not on ordinary returns to capital, but rather on a variation over time in markups that reflects "variation in market power." 106 This finding seems quite supportive of the proposition that variations in anticompetitive practices help explain the pattern of economic inequality. Moreover, because Rognlie is focused solely on Piketty's claim that rising economic inequality reflects the tendency of capital returns to outstrip labor income, Rognlie does not address the additional point that increasing anticompetitive profits also increases economic inequality within the labor market by increasing compensation for corporate executives relative to others.

To the extent the recent rise in economic inequality does reflect a rise in anticompetitive practices, the recent increase in horizontal shareholdings may not be the sole or main cause of that rise. As the graph above shows, economic inequality starts to rise around 1980. This coincides with the post-1980 increase in horizontal shareholdings caused by the growth of institutional investor stockholdings, which in turn is related to ERISA and tax rule changes that spawned 401(k)s in 1980 and greatly expanded IRAs in $1981 .{ }^{107}$ But the rise of economic inequality also coincides with President Reagan's 1980 appointment of Bill Baxter to head the Antitrust Division, which ushered in the modern era of more conservative antitrust enforcement influenced by Chicago School critiques of prior activist antitrust enforcement. Although those critiques have never been fully accepted, they have been persuasive enough with agencies and courts to continue to narrow antitrust enforcement in subsequent administrations, including Democratic ones. To the extent one thinks that at least some of that narrowing has incorrectly allowed more anticompetitive mergers and conduct, the variations in economic inequality may reflect variations in general antitrust enforcement. ${ }^{108}$

Further research will be necessary to disentangle these multiple contributors to changes in economic inequality. Nonetheless, the evidence so far suggests that increasing horizontal shareholdings probably have played some significant role in increasing economic inequality.

${ }^{106}$ Id. at 1, 3-4, 15-16.

107 See http://www.learnvest.com/knowledge-center/your-401k-when-it-was-invented-andwhy/; http://www.taxpolicycenter.org/taxtopics/encyclopedia/IRAs.cfm.

108 See generally Jonathan B. Baker \& Steven C. Salop, Antitrust, Competition Policy, and Inequality, 105 GEORGETOWN L.J. 1 (2105) (arguing generally that increased antitrust enforcement would help reduce economic inequality). 
In any event, to the extent one is concerned about this recent rise in economic inequality, which has become a major policy concern for many, ${ }^{109}$ preventing anticompetitive horizontal shareholdings are a useful method for reducing economic inequality because making markets more competitive reduces the returns to capital relative to returns to labor and tends to reduce differences in executive compensation. Antitrust enforcement against horizontal shareholdings is also far more feasible than Piketty's solution of imposing a global wealth tax. ${ }^{110}$ Getting Congress to enact to a wealth tax seems politically unrealistic, and it seems even more fanciful that enough nations would simultaneously adopt similar taxes to prevent capital flight to other nations with lower wealth taxes. Others suggest a progressive consumption tax is a better solution. ${ }^{111}$ But a new consumption tax also seems politically unfeasible in the United States and might, if seriously pursued, lead to consumption flight to other nations absent international agreements to impose the same consumption tax everywhere. In contrast, as shown next in Part III, current U.S. antitrust laws already authorize enforcement against horizontal shareholdings, so all that would be required are antitrust agencies willing to enforce the law, or private plaintiffs willing to bring antitrust actions that could be highly lucrative.

Moreover, wealth or consumption taxes have the cost that to some extent they retard economic growth. The precise extent to which they retard growth is much debated, and slower growth may be a cost worth bearing to achieve more equal distributions. But antitrust enforcement against anticompetitive horizontal shareholdings has the advantage that it would increase market output and thus affirmatively increase economic growth. Unlike a tax increase, antitrust enforcement not only divides the pie more equitably, but also increases the size of the pie itself.

In short, although perhaps not a full solution to the problem of economic inequality, antitrust enforcement against horizontal shareholdings certainly seems the remedy that has the least political and economic cost associated with it. Indeed, it would likely produce affirmative benefits to economic growth and employment.

But does existing antitrust law allow enforcement against anticompetitive horizontal shareholdings? That is the topic I address next.

109 Others disagree it is a problem in itself. See, e.g., N. Gregory Mankiw, Yes, $r>g$. So What?, 105(5) American Economic ReVIEW: PAPERs \& ProceEdings 43, 46 (2015)

${ }^{110}$ PIKETTY, supra note , at 528-30, 571-575.

${ }^{111}$ Mankiw, supra note m, at 45-46; Alan J. Auerbach \& Kevin Hassett, Capital Taxation in the Twenty-First Century, 105(5) AmERICAN ECONOMIC ReVIEW: PAPERs \& PROCEedings 38, 41 (2015) 


\section{Taking Legal ACtion Against Anticompetitive Horizontal SHAREHOLDING}

Some have suggested that, absent evidence that institutional investors are directing corporate managers not to compete on price, the antitrust laws provide no remedy, even though horizontal shareholdings naturally create incentives for anticompetitive pricing. ${ }^{112}$ They suggest the solution is instead to have Congress enact a new law that takes away tax advantages for retirement funds that invest in any mutual funds that have a significant number of shares in more than one firm in a specific market. ${ }^{113}$

Such a solution faces a serious uphill battle politically. It is hard to get Congress to enact new laws when there is serious political conflict over them, as there surely would be for a new statute that takes away tax advantages from retirement funds and harms institutional investors, the persons who invest in them, and the corporate managers who benefit from lower competition and higher compensation. Such a solution also seems seriously overbroad, because Part I shows that both economic theory and empirical evidence indicate that such horizontal shareholdings are likely to create significant anticompetitive problems only when the market concentration is high and the horizontal shareholdings are substantial, with the empirical evidence and antitrust guidelines indicating the relevant thresholds are an HHI above 2500 and a $\triangle$ MHHI above 200.

Such a solution is also unnecessary because, as I explain below, current antitrust law already provides a remedy against horizontal shareholdings. That antitrust remedy is far more politically feasible. All it requires is the will to bring cases by one of the two federal antitrust agencies, or any one of the fifty states, or by any set of injured plaintiffs who could bring lucrative private actions for treble damages to recover the higher prices caused by anticompetitive horizontal shareholdings. The antitrust remedy is also far less overinclusive because it is limited to cases where horizontal shareholdings can have anticompetitive price effects; i.e., when they are significant enough to make $\Delta \mathrm{MHHI}$ substantial and affect corporations in markets that are sufficiently concentrated to result in a MHHI over 2500. Absent those conditions for anticompetitive effects, we currently lack a sound basis to interfere with shareholder diversification across horizontal rivals.

To be sure, evidence that institutional investors are directing corporate managers not to compete with horizontal rivals would probably be necessary to bring a criminal

112 Posner \& Weyl, supra note .

113 Posner \& Weyl, supra note . 
case against the institutional investors under Sherman Act $\S 1$. But Clayton Act $\S 7$ is far broader. Although it is often loosely called a merger statute, this provision actually bans any stock acquisition "where in any line of commerce or in any section of the country, the effect of such acquisition may be substantially to lessen competition."114 As Part I showed, the economic models of O’Brien and Salop, as well as the econometric study of Azar, Schmalz and Tecu, both indicate that the acquisition of stock in horizontal competitors by institutional investors is likely to substantially lessen competition whenever that acquisition produces a substantial increase in MHHI in a concentrated market. All such stock acquisitions are thus potentially challengeable under Clayton Act $§ 7$.

The so-called passive investor exception is not to the contrary. What the relevant provision provides is that Clayton Act §7's condemnation does "not apply to persons purchasing such stock solely for investment and not using the same by voting or otherwise to bring about, or in attempting to bring about, the substantial lessening of competition." 115 Getting the benefit of this exception thus requires proving both of the following elements: (1) the stock acquisition must be solely for investment; and (2) the acquired stock must not actually be used to lessen competition substantially or to attempt to do so. ${ }^{116}$

The first element requires proof that the investment is purely passive, which excludes not only investments that give working control, but also investments that give the stock acquirer any influence over the corporation's business decisions or access to the corporation's sensitive business information. ${ }^{117}$ This antitrust notion of passivity is totally different from what institutional investors usually mean when they call themselves "passive investors," which is that they have a passive investment strategy, as with an index fund, and thus make no active decision about which corporate stock to buy but rather purchase stock based on some index or

${ }^{114}$ Clayton Act $\S 7,15$ U.S.C. § 18.

11515 U.S.C. $\S 18$ (emphasis added).

${ }^{116}$ United States v. Tracinda Inv. Corp., 477 F.Supp. 1093, 1098 (C.D. Cal. 1979); Anaconda Co. v. Crane Co., 411 F.Supp. 1210, 1219 (S.D.N.Y. 1975).

117 United States v. E.I. du Pont de Nemours \& Co., 353 U.S. 586, 597-606 (1957) (even absent evidence that 23\% stake conferred working control, passive investment exception did not apply where the investing firm tried to influence business decisions); Tracinda, 477 F.Supp. at 1098; Anaconda, 411 F.Supp. at 1218-19; United States v. Amax, Inc., 402 F.Supp. 956, 974 (D. Conn. 1975); United States v. Gillette Co., 55 Fed. Reg. 28,312 (July 10, 1990); U.S. DOJ/FTC Horizontal Merger Guidelines § 13 (2010) (agencies will consider whether partial stock acquisition lessens competition by giving the acquirer an ability to influence the target or access to the target's confidential business information). 
formula. This does not mean passive ownership because institutional investors usually do actively seek to influence corporate management, including by direct communication, having investor executives serve on corporate boards, and voting their shares to favor positions and management that best advance their investor interests. ${ }^{118}$ Vanguard stresses their funds are "passive investors, not passive owners." strategy does not prevent them from being active owners. ${ }^{120}$ A recent survey of institutional investors found that $63 \%$ admitted they engaged in direct discussions with corporate management, 53\% admitted they tried to influence corporate management by voting against them, and only $19 \%$ said they made no efforts to influence corporate management. ${ }^{121}$ Active ownership like this is inherently nonpassive under antitrust law.

Indeed, some institutional investors stress that because passive investment strategies (like index funds) mean they are necessarily long-term investors in many firms, they have even stronger incentives to influence corporate governance. ${ }^{122}$ In short, precisely because passive investment strategies prevent threats of "exit", they give institutional investors with such strategies even more incentives to focus on exercising "voice."123 But that voice is precisely what makes their investments active for antitrust purposes.

The influence that negates the passive investor exception need not involve any direct communication from horizontal shareholders to managers. Managers know who their shareholders are and what best serves their interests. ${ }^{124}$ They also know that institutional investors vote on board of director elections and on shareholder

${ }^{118}$ Azar, Schmalz \& Tecu, supra note , at 4-5, 33-36; Mike Scott, Passive investment, active ownership, FinANCIAL TIMES (April 6, 2014)(quoting former TIAA-CREF head of corporate governance as saying “" "Having a passive investment strategy has nothing to do with your behaviour as an owner," and the head of head of corporate governance at State Street Global Advisors as saying “" As an asset manager with one of the world's largest passive offerings and a near-perpetual holder of index constituents, active ownership represents the tangible way in which SSgA can positively impact the value of our underlying holdings... The option of exercising our substantial voting rights in opposition to management provides us with sufficient leverage and ensures our views and client interests are given due consideration.”)

${ }^{119}$ Azar, Schmalz \& Tecu, supra note , at 33

${ }^{120} \mathrm{Id}$. at 33.

121 Joseph A. Mccahery, Zacharias Sautner \& Laura T. Starks, Behind the Scenes: The Corporate Governance Preferences of Institutional Investors 1, 8, 31 (May 2015)

${ }^{122}$ Id. at 35.

123 Albert O. Hirschman, EXIT, Voice, AND Loyalty (1970).

${ }^{124}$ Azar, Schmalz \& Tecu, supra note , at 5, 11. 
proposals. ${ }^{125}$ Although large institutional investors may have many separate funds, they jointly exercise the voting of all their funds for maximum effect. ${ }^{126}$ Whenever such voting influences corporate management, as it surely does for institutional investors with large stockholdings, it voids the passive investor exception.

The second element means that even when an investor can show it is purely passive in the antitrust sense, the passive investor exception does not apply if the acquired stock is actually used, by voting or otherwise, to lessen competition substantially or to attempt to do so. The effect, as courts have noted, is that the passive investor exception is not really an exception at all, but rather means that a different burden of proof applies to purely passive investments. ${ }^{127}$ Whereas an active investment can be condemned if it may substantially lessen competition, a passive investment can be condemned only if it actually does so or was intended to do so. A purely passive investment could, for example, actually lessen competition if it simply lessens the incentives of the firms to compete with each other, even though the investors never use their stock to affirmatively influence business conduct. ${ }^{128}$ Thus, even if an institutional investor was purely passive, proof that horizontal shareholdings actually lessened competition, such as the Azar, Schmalz and Tecu study showing that it actually raised airline prices, would negate the passive investor exception and leave the horizontal shareholders subject to challenge under Clayton Act $\S 7$.

Further, even if Clayton Act $\S 7$ did not apply, a purely passive investment that created horizontal shareholdings that produced likely anticompetitive effects would be reviewable under Sherman Act $\S 1$ because the stock acquisition is an agreement whose anticompetitive effects would constitute an unreasonable restraint of trade. Criminal penalties are unlikely but civil remedies, including damages and injunctive relief, would still apply. Such acquisitions would also constitute an unfair method of competition under FTC Act §5, though that is only enforceable by the FTC.

Nor do filing exceptions alter these substantive rules. Under the Hart-Scott-Rodino Act, those who plan to acquire "voting securities or assets" of another firm must (absent an applicable exception) file information with the federal antitrust agencies

125 Id. at 34.

${ }^{126}$ Id. at 34 .

127 Tracinda, 477 F.Supp. at 1098 \& 1099 n.5; Anaconda, 411 F.Supp. at 1218-19.

128 U.S. DOJ/FTC Horizontal Merger Guidelines § 13 (2010); O’Brien \& Salop, supra note, at _; Gilo, supra note, at 88. See also United States v. Dairy Farmers of Am., Inc., 426 F.3d 850, 859-860 (6th Cir. 2005) (stock acquisition can lessen competition even if it does not confer control or influence over the acquired firm). 
if the dollar amounts involved exceed certain thresholds. ${ }^{129}$ By statute, this filing requirement does not apply if the acquired voting securities are both (1) solely for investment purposes and (2) do not give the acquirer more than $10 \%$ of the target's voting securities. ${ }^{130}$ But even if this filing exception for passive investors under $10 \%$ applies, that only means that failing to file information about the stock acquisition is not a violation of the filing rules. Even when no filing is required, the stock acquisition itself remains challengeable under the substantive standards noted in the prior paragraphs.

Moreover, the FTC and DOJ (which have authority to adopt exemptions from the filing requirement ${ }^{131}$ ) have made plain that the criteria for meeting the passive investor filing exemption are quite strict. Their regulation treats a stock holding as solely for investment only "if the person holding or acquiring such voting securities has no intention of participating in the formulation, determination, or direction of the basic business decisions of the issuer."132 The agencies' report regarding the purpose of this provision states:

merely voting the stock will not be considered evidence of an intent inconsistent with investment purpose. However, certain types of conduct could be so viewed. These include but are not limited to: (1) Nominating a candidate for the board of directors of the issuer; (2) proposing corporate action requiring shareholder approval; (3) soliciting proxies; (4) having a controlling shareholder, director, officer or employee simultaneously serving as an officer or director of the issuer; (5) being a competitor of the issuer; or (6) doing any of the foregoing with respect to any entity directly or indirectly controlling the issuer. ${ }^{133}$

Given the above evidence that institutional investors are usually active owners who participate in corporate business decisions by discussing them with managers, this filing exemption would not apply even if the institutional investor did own less than $10 \%$ of a corporation's stock. Nor would it apply to institutional investors who have executives that serve on corporate boards or who nominate directors for corporate boards. However, this filing exemption could apply to institutional investors who do nothing but vote shares and have less than $10 \%$ of corporate stock. Given the

\footnotetext{
12915 USC $\S 18 \mathrm{a}(\mathrm{a})$.

13015 USC $\S 18 a(c)(9)$.

13115 USC $\S 18 \mathrm{a}(\mathrm{d})(2)(\mathrm{B})$.

13216 C.F.R. § 801.1(i)(1).

13343 Fed. Reg. 33,450, 33,465 (1978).
} 
findings of Azar, Schmalz and Tecu, this filing exemption is unwise because horizontal investors who individually have less than $10 \%$ of corporate stock can nonetheless significantly alter the competitive incentives of corporate management, especially because collectively their share of corporate stock may be far higher than $10 \%$. The FTC and DOJ should thus modify this regulation to require filings whenever some set of shareholders collectively owns more than $10 \%$ of the stock in corporations that are competitors. Otherwise, the government agencies are just depriving themselves of useful information about potentially anticompetitive acquisitions.

Another FTC/DOJ regulation provides a filing exemption for any institutional investor who acquires less than $15 \%$ of the stock of any corporation. ${ }^{134}$ Again, this filing exemption does nothing to alter the substantive standards. Such a stock acquisition remains illegal if it is either (a) active and may substantially lessen competition or (b) purely passive and actually lessens competition or is intended to do so. This filing exemption simply deprives the antitrust agencies of useful information about potentially anticompetitive acquisitions. It reflects a prior time when the anticompetitive effects of horizontal shareholdings by institutional investors were not understood, and the FTC and DOJ should repeal this filing exception.

Indeed, the authority of the FTC and DOJ to adopt filing exemptions applies only to "classes of persons, acquisitions, transfers, or transactions which are not likely to violate the antitrust laws." 35 The recent empirical work has proven that the agencies were mistaken to assume that an institutional investor's acquisition of stock is unlikely to harm competition if that investor "merely votes" shares or individually acquires less than 15 percent of a corporation's stock. Thus, this recent empirical work may well mean that the agencies are obligated to eliminate these filing exemptions. With those exemptions eliminated, the agencies would benefit from far more systematic information about the extent of horizontal shareholding in our economy.

Regardless of whether the regulatory filing exemption are altered, the federal agencies can and should challenge any stock acquisitions that can be shown to have produced anticompetitive horizontal shareholdings. Given their own guidelines and the empirical results summarized in Part I, they should investigate any stock acquisitions that create a $\Delta \mathrm{MHHI}$ of over 200 in a market with an HHI over 2500.

\footnotetext{
13416 C.F.R. § 802.64.

13515 USC $\S 18 a(d)(2)(B)$.
} 
Further, they should take into account that while a true merger creates integrative efficiencies that might offset the effect of increasing concentration, a stock acquisition that creates horizontal shareholdings generates no such offsetting integrative efficiencies.

Even if the federal agencies do not act, institutional investors should consider the fact that their current holdings make them vulnerable to private antitrust lawsuits. Although most Clayton Act $\S 7$ challenges have been brought by the federal antitrust agencies, any person financially injured by a stock acquisition that creates anticompetitive horizontal shareholdings has standing to bring an antitrust to recover treble damages and get injunctive relief ending the horizontal shareholdings. ${ }^{136} \mathrm{~A}$ class of passengers injured by paying higher airline fares because of horizontal shareholdings on a concentrated route could, for example, bring suit on the theory that the stock acquisitions by institutional investors that created those horizontal shareholdings harmed the passengers by lessening airline competition. ${ }^{137}$ Likewise, any state could bring an antitrust suit on behalf of residents injured by the horizontal shareholdings created by such stock acquisitions. ${ }^{138}$

If the stock that creates anticompetitive horizontal shareholdings was acquired more than four years ago, the statute of limitations might be an obstacle to a damages claim. ${ }^{139}$ However, whether brought by a private or public actor, antitrust claims seeking injunctive relief have no statute of limitations. ${ }^{140}$ That would suffice to force the divestiture of any horizontal shareholdings that had anticompetitive effects. Even for a damages claim, it is usually the case that institutional investors will have acquired at least some of the stock in the last four years. Further, the statute of limitations begins to run only when a cause of action "accrues", which means both that the defendant committed a violation and that this violation injured the plaintiff. $^{141}$ For example, if an initially passive investment did not become a violation until it was later exercised actively, the statute of limitations could not begin to run until that active use started. Likewise, if a stock acquisition did not raise prices until later, perhaps because market concentration later increased or other

13615 U.S.C. $\S \S 4,12,15,25-26$; Reiter v. Sonotone Corp., 442 U.S. 330, 339 (1979).

${ }^{137}$ Federal Rule of Civil Procedure 23.

13815 U.S.C. § 15c.

13915 U.S.C. $\S 15 b$.

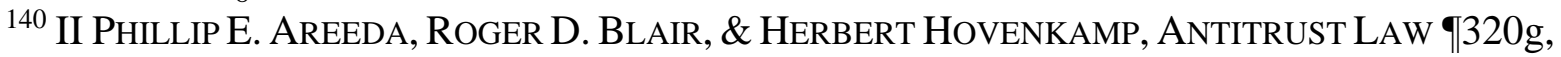
at 237 (2d ed. 2000). Injunctive relief might be barred by the doctrine of laches when suit is unjustifiably delayed, id., but that doctrine hardly seems applicable here given that the ongoing injuries from horizontal shareholdings have only just now been revealed.

141 Zenith Radio Corp. v. Hazeltine Research, Inc. (Zenith II), 401 U.S. 321, 338 (1971). 
horizontal shareholders later made acquisitions that made $\Delta \mathrm{MHHI}$ substantial, then the statute of limitations would not start until the price injury started. Indeed, some courts have held that the statute of limitations cannot begin to run until the plaintiff discovers his injury. ${ }^{142}$ Because any injury from horizontal shareholdings was generally unknown before the Azar, Schmalz and Tecu empirical study came out, it seems unlikely that any plaintiffs could have discovered their injury from horizontal shareholdings before then.

Moreover, the statute of limitations is tolled pending any government suit ${ }^{143}$ or if any one of three other tolling doctrines is met. (1) The statute of limitations is tolled during any period where the defendant fraudulently concealed the violation, as long as the plaintiff was unaware of the concealed violation despite due diligence. ${ }^{144}$ Thus, the statute of limitations could be tolled if the investors concealed their horizontal shareholdings or concealed the use of their stock to lessen competition among the corporations in which they are invested. (2) When a defendant engages in a continuing series of anticompetitive conduct, then each act that is part of the violation and injures the plaintiff restarts the period of limitations, even though the illegal conduct began much earlier. ${ }^{145}$ Thus, if the horizontal shareholdings produce fresh injuries, such as new transactions at inflated prices in the last four years, then the plaintiff should be able to recover for the overcharge it suffered on transactions within the last four years. ${ }^{146}$ (3) Even if the misconduct and injury have occurred, the statute of limitations does not begin to run until the injury becomes sufficiently non-speculative to form the basis for reasonably ascertainable damages. ${ }^{147}$ The logic is fairly straightforward: a plaintiff cannot be penalized for delaying suit if an earlier suit would have been barred on the grounds that its damages had not yet become reasonably ascertainable. This tolling doctrine would seem applicable to any new cases against horizontal shareholdings because, until the Azar, Schmalz and Tecu empirical study came out, plaintiffs likely had no non-speculative basis for proving injury from horizontal shareholdings.

While the statute of limitations issues would likely be resolved differently in different cases and by different courts, the bottom line is that institutional investors with significant horizontal shareholdings in firms that compete in concentrated markets face a serious risk of antitrust liability and damages. To minimize their

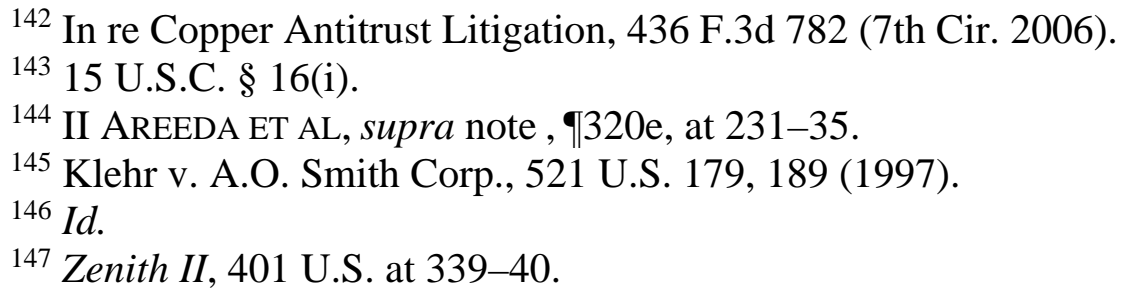


antitrust risk, they may thus want to consider voluntarily divesting themselves of significant shareholdings in any horizontal competitors who compete in concentrated markets. This result can be achieved with minimal loss of diversification benefits because they can remain invested in one firm in each industry and thus remain diversified across all industries in the economy. Further, concentrating their industry investments in one firm for each market will give them a greater share of corporate voting power in the firms in which they invest. This should strengthen their ability to improve corporate governance in ways that improve management efficiency and benefit shareholders without harming competition and consumers. Another alternative might be avoid having any influence whatsoever over corporate policy by not only refraining from any communication with management, but also committing not to vote their stock or to vote the stock in proportion to how nonhorizontal shareholdings vote. But that alternative seems likely to less desirable because having strong institutional investors lessens the separation of ownership and control on a host of corporate issues that do not raise anticompetitive concerns.

Contrary to the claims of some, none of this means that index funds are inherently illegal under antitrust law. ${ }^{148}$ First, as I have stressed, institutional investor holdings are likely to be anticompetitive only when the holdings are in a concentrated product market (an HHI > 2500, or roughly four or fewer major firms) and substantial horizontal shareholdings exist (the same institutional investors have large enough holdings in the same competitors to make $\Delta \mathrm{HHI}>200$ ). Second, while institutional investors as a whole hold $80 \%$ of S\&P 500 corporate stock, only about $22 \%$ of institutional investor stock was indexed as of 2010. ${ }^{149}$ Thus, if non-indexed funds divested their stock in some competitors in concentrated markets where substantial horizontal shareholdings exist, that would likely eliminate the problem in those markets. Third, funds could index investments across industries, without doing so across each firm in each industry, and achieve nearly the same diversification benefits. Fourth, if index funds alone would create a problem of anticompetitive horizontal shareholding in a concentrated market, and those index funds feel the benefits of diversification across all firms in that market exceed the benefits of influencing corporate governance, they could commit not to communicate with management or vote their shares.

148 See Matt Levine, Capital Charges and Illicit Indexing (July 21, 2015), available at http://www.bloombergview.com/articles/2015-07-21/capital-charges-and-illicit-indexing

(incorrectly asserting that this was my claim in a prior draft of this article).

149 See Stan Luxenberg, Are Index Funds' Distorting Markets? (Sept 10, 2010), available at http://wealthmanagement.com/news/are-index-funds-distorting-markets. 
Nonetheless, while index funds today probably lack enough stock to alone create anticompetitive horizontal shareholdings in many industries, index funds have been growing rapidly in a way that increases the problem because they are inherently invested across horizontal competitors in each industry. Further, they have become increasingly active in using their shares to influence corporate management. The anticompetitive problem of horizontal shareholding means there is some antitrust cap on the share of the stock market that in the future can be allowed to go into fullyindexed funds that actively vote shares. To avoid these anticompetitive problems, index funds must at some point either stop growing, give up any voting influence, or become indexed across industries rather than indexed across all competitors in each industry.

\section{CONCLUSION}

Horizontal shareholdings are omnipresent in our economy given that institutional investors now own $80 \%$ of all stock in S\&P 500 corporations. Economic models and recent empirical work show that such horizontal shareholdings are likely to anticompetitively raise prices when they are significant and the owned businesses compete in a concentrated market. Such horizontal shareholdings can help explain fundamental economic puzzles like the use of seeming perverse methods of executive compensation, the current failure of corporations to use high profits to expand output and employment, and the recent rise in economic inequality. These harmful economic effects could and should be reduced by using current antitrust law to challenge the stock acquisitions that have created such anticompetitive horizontal shareholdings. 